\title{
Public-Private-Civil Society Partnership: A Gateway to Ensuring Good Governance Practices of Vocational Education Programme in South-South Nigerian Federal Universities
}

\author{
James Edokpolor $^{1^{*}}$, Adesuwa Imafidon ${ }^{2}$ \\ ${ }^{1,2}$ Benson Idahosa University, 1 University Way, Off Upper Adesuwa Grammar School Road, Benin City, \\ P.M.B. 1100, NIGERIA
}

DOI: https://doi.org/10.30880/jtet.2019.11.03.015

Received $8^{\text {th }}$ September 2018; Accepted $26^{\text {th }}$ September 2019; Available online $30^{\text {st }}$ September 2019

\begin{abstract}
There is an increasing evidence that education generally and vocational education particularly in Nigeria is facing serious challenge of financial resource mismanagement, which seem to be traceable to high level of corruption or corrupt practices exhibited by school administrators. This unpleasant situation has contributed to lack of effectiveness and efficiency, accountability, transparency, and integrity in the utilization of funds for execution of projects. However, the quest to achieve the main objectives of vocational education appears to be rather unrealistic. Therefore, the issue of mismanagement or lack of clarity in the utilization of funds for execution of projects have called for the coalition of all major stakeholders within and outside Nigeria so as to help bypass the corrupt governance of vocational education programme. This study aims at investigating the extent to which public-privatecivil society partnership (PPCSP) can help in establishing good governance practices of vocational education programme in Federal Universities in South-South geopolitical region of Nigeria. Four research questions were raised and answered using the Mean and standard deviations descriptive statistics, and four corresponding null hypotheses were formulated and tested using the t-test statistic. A descriptive survey research design was employed for the study. The study population comprised of all the vocational education lecturers in South-South Nigerian Federal Universities. A 4-point scaled questionnaire was administered to 154 vocational education lecturers. The instrument was validated by 4 experts, and the reliability coefficient using Cronbach alpha was $\alpha=.90$. The analysis of the data collected revealed that to a very high extent PPCSP can help in promoting good governance practices (e.g., effectiveness, efficiency, transparency, accountability, and integrity) in the utilization of funds for execution of projects by vocational education administrators. When the corresponding null hypotheses were tested, the study found no significant difference in the Mean responses of male and female vocational education lecturers as regards the extent to which PPCSP can help in promoting good governance practices in the utilization of funds for execution of projects. Based on these findings, there is the need for all the major stakeholders of vocational education within and outside Nigeria to collaborate in order to promote good governance practices in the utilization of funds for execution of projects by vocational education administrators.
\end{abstract}

Keywords: Corruption, corrupt practices, execution of projects, good governance practices, PPCSP, utilization of funds, vocational education administrators.

\section{Introduction}

Many countries around the world are increasingly pressing for policy reforms, especially in the area of vocational education governance. The key focus of these policy reforms is on how vocational education institutions might establish the principles of good governance (Cedefop, 2011a; European Training Foundation, ETF, 2011a; 2013; 2014). The need for these policy reforms is because quality governance of vocational education institutions is of paramount interest to all major stakeholders. As such, the quality governance of vocational education institutions is of important interest to parents 
who usually lead the way on how the vocational education programme is regarded, to the professional associations, to the employers of labour who are seriously in need of skilled and competent graduates, both to the youths and the adults who may need training or re-training and to the civil society actors, including the labour unions.

Governance has become an emerging area of inquiry, but studies so far have concentrated on the assessment and evaluation of governance principles, rather than how to showcase the best practices of ensuring good governance, which provide the opportunity for vocational education institutions to respond to the needs of multiple clients and stakeholders within and outside Nigeria. For example, the Organization for Economic Co-operation and Development (OECD, 2013) report provides an international comparative analysis and policy advice to countries on how evaluation and assessment arrangements can be embedded within a consistent framework to improve the quality, equity and efficiency of educational institutions. Kitchen, Fordham, Hendarson, Looney and Maghnouj (2017) also investigated the role of assessment and evaluation in the education governance in Romania. But in this current study, the authors' focused on the role of multistakeholders' partnership in promoting good governance of vocational education. Although, evaluation and assessment are not necessarily wrong or bad, but in vocational education sector the concern must be whether evaluation and assessment have an important role in ensuring greater effectiveness and efficiency, transparency, accountability and integrity in the utilization of funds for execution of projects.

Vocational education programme that is well-governed through the effective participation of all major stakeholders would assist in equipping students with requisite skills and competencies required to engage in entrepreneurial and lifelong learning activities. However, these outcomes have been found to be beneficial, in particular, to those who are affected by unemployment and underemployment (Edokpolor, 2018a; Edokpolor, 2018b; Edokpolor, 2018c; Edokpolor \& Muritala, 2018; Edokpolor \& Oduma, 2018; Edokpolor \& Owevbuigie, 2017). The term "vocational education" is concerned with the acquisition of skills and competencies for the world of work to increase opportunities for sustainable livelihoods, productive work, personal empowerment and socio-economic development in rapidly changing work environments (MacLean \& Wilson, 2009). Vocational education can also be described as an education which is geared towards the training of low-level manpower, such as, operatives, artisans, craftsmen and master craftsmen for commerce, industry, agriculture, and ancillary services (British Council, 2017).

Despite the potential roles, vocational education programme continues to face serious issues and challenges, especially in the area of financial resources optimization, which seem to be traceable to high level of corruption or corrupt practices exhibited by administrators. Nwadiani and Omoike (2006) argued that there is corruption in all aspects of educational system (including vocational education programme). They specifically pointed out that corruption has manifest in contract inflation, in direct procurement of material resources, in payment of salaries, especially to "ghost workers". They also lamented that there is inflation in the number of students for the purpose of drawing more funds for wrong uses. All these indicators of corrupt practices serve as enormous drains to the financing of education, especially in the vocational education sector, which tend to have a direct effect in the realization of its main objectives in Nigeria and every other parts of the world.

There is an important evidence from the above discussions to suggest that corruption is a key issue and challenge that contributes to the poor governance of vocational education institutions in Nigeria. As such, a new report from the Transparency International (2017a) recommends putting in place strong mechanisms to avoid the mismanagement and increase the transparency and availability of information to ensure the committed funds are spent effectively and accounted for. Therefore, the issue of mismanagement and a lack of clarity about how funds for vocational education are spent have called for the participation and involvement of all major stakeholders within and outside Nigeria to help bypass corrupt and ineffective governance. The participation and involvement of all major stakeholders of vocational education in ensuring good governance practices have potential in promoting economic development and enhancing the matching of labour supply to market needs. It would also provide the opportunity for vocational education administrators to have "value for money". The Transparency International (2017b) further stipulated that the term "value for money" is a principle in organizational procurement that refers to the level of economy, efficiency, effectiveness, and equity in the utilization of funds for execution of projects.

The participation and involvement of all major stakeholders in ensuring good governance practices of vocational education can be referred to as public-private-civil society partnerships (PPCSP). To the World Economic Forum (WEF), PPCSP is a model of cooperation in which actors from public, private and civil society sectors bring together core complementary competencies, capabilities and resources in achieving good governance practices (US Agency for International Development, 2008). The concept of PPCSP involve a reciprocal obligations and mutual accountability, including either voluntary or contractual relationships; the sharing of investment (financially or otherwise), reputational risks (rather than one-dimensional transfer of risks to private sector), and joint responsibility in execution of projects (WEF, 2005). Despite the fact that current study (e.g., Edokpolor \& Imafidon, 2017) have established the important role of partnerships in promoting good governance, the authors of this current study found no empirical study that specifically examine the important role of PPCSP in promoting good governance of vocational education. However, a recent study showed that the male vocational education lecturers do not significantly differ in their perceptions than the female vocational education lecturers as regards the various ways public and private sector partnerships can enhance the realization of vocational education programme objectives (Akpomudjere, 2015). The study conducted by Akpomudjere 
(2015) has specifically support the notion that public and private sector partnerships has a role to play in the realization of vocational education programme objectives in Nigeria.

The term "PPCSP" must not be confused with the term "public-private partnership" or "PPP". PPCSP covers a wide range of partnerships among the United Nations agencies, International Financial Institutions, and civil society organizations (Education International, 2009), whereas, the PPP involves a contractual agreement between public education institutions and private sector actors, aimed at managing public services (Ball \& Youdell, 2008; Centre for European Studies, 2006; OECD, 2008). Although, there are many forms of PPP (e.g., students' industrial work experience scheme, teaching practice, internship, and work visit) where private organizations work with public vocational education institutions to enhance the acquisition of skills among students (Egbri \& Chukwuedo, 2014; Ekpenyong, 2011). Other forms of PPP where private organizations work with public vocational education institutions in specialized areas, includes, resources (financial, personnel, and facilities) management, curriculum development, students mentoring, facility donation and maintenance services for the promotion of good governance (Adewuyi \& Okemakinde, 2013). However, the effort of PPP towards promoting good governance is actually not good enough to achieve the main objectives of vocational education programme, probably because the public vocational education and private sector actors alone cannot effectively manage such a programme due to its capital-intensive nature. Therefore, there is a need to utilize a broader coalition of all major stakeholders, rather than PPP in promoting good governance practices in vocational education programme in Nigeria and other parts of the world. Such a partnership that involves a broader coalition of major stakeholders (e.g., employers of labour, civil society organizations, government agencies, parents, and international donor agencies) can be created for the purpose of ensuring that vocational education administrators are effective and efficient, transparent, accountable and committed to moral and ethical standards in the utilization of funds for execution of projects. Therefore, the PPCSP can be viewed as a mechanism to address the issue of corrupt practices, such as fraud, embezzlement and rigged bidding processes in infrastructure-related procurement.

Previous studies defined corruption as the misuse of entrusted power for personal gain (Aurora, Teixeira, \& Luís, 2015; Neudorfer \& Theuerkauf, 2014; Transparency International, 2009; 2016, 2017a). In the view of Hammed (2018), corruption is an act of dishonesty or unlawful behaviour of government officials. Corruption can also be defined as the siphoning of funds made available for execution of projects (Transparency International, 2008). However, the conceptualization of corruption supports the notion that vocational education programme with high level of poor governance practices (such as, lack of effectiveness, efficiency, accountability, transparency and integrity) can often lead to industrial shrinkage, technological backwardness and socio-economic degradation. Therefore, the existence of poor governance practices in vocational education programme is a treat to sustainable economic development of nations.

According to the Oxford Advanced Learner's Dictionary (2010), governance means 'the activity of governing a country or controlling a company or an organization'. Simply put, governance is the process by which decisions are made and implemented (Sharma, Sadana, \& Kaur, 2013). Governance also involves organizing collective action through the processes of selecting goals, making decisions, allocating resources, implementing policies and generating feedback (Pierre \& Peters, 2005). Governance also involves the distribution of authority and functions among the units within a larger entity, the modes of communication and control among them, and the conduct of relationships between the entity and the surrounding environment (Blom \& Cheong, 2010). Governance determines how power is exercised, how decisions are taken, and how stakeholders (including citizens) have their say (Oliver, 2010). Based on this conceptual clarification, it is worthy of note that 'governance' should be 'good'. Essentially, 'governance' becomes 'good' when it is operated in accordance with legal, moral and ethical principles and standards as perceived by people in the society (Oronsaye, 2016).

Abrams, Borrini-Feyerabend, Gardner and Heylings (2003) opined that good governance is a fair and effective way of exercising powers (means) in order to meet the objectives (ends) of institutions. They added that good governance is founded upon the capacity and reliability of institutions to effectively respond to problems and achieve social unity through various forms of consultation, negotiation and multi-stakeholders' agreements. The ETF (2013) stipulated that governance in vocational education can be defined as a model for vocational education policy-making management based on involving stakeholders at all levels (e.g., sectorial, local or regional, national or international) for the setting, implementing and monitoring of objectives.

Good governance, therefore, involves the engagement and participation of major stakeholders in formulating, implementing, reviewing and monitoring of policies and strategies for the development of vocational education. The ETF (2013) tells us that good governance in vocational education refers to the transparent and accountability management of policies for the purpose of making the vocational education a source of attractiveness associated with excellence to improve its image. However, good governance in the vocational education would help in facilitating the right implementation of policies in ways that are effective, efficient, transparent, accountable, equitable and coherent. While maintaining mechanisms to take on board all relevant stakeholders (such as, civil society, training providers, industry owners, parents, labour unions and faith-based organizations), in the development, financing and implementation of quality assured programmes within the vocational education policy framework. Therefore, vocational education governance relies on effectiveness and efficiency, transparency, accountability, and integrity so as to be able to achieve its set objectives and contributes to economic growth and development of nations. 
Good governance of vocational education therefore is practically expressed in effectiveness and efficiency, transparency, accountability, and integrity in the utilization of funds for execution of projects. The effectiveness of vocational education on the one hand refers to the degree to which the vocational education programme realizes its broad objectives. It also entails the provision of vocational education services and quality graduates that employer of labour value. The efficiency of vocational education on the other hand refers to the amount of resources (money, people and materials) the vocational education programmes used to achieve its broad objectives. It is also based on how much resources are necessary for the production of qualified graduates. The ETF (2013) stipulated that transparency involves sharing information and acting in an open manner. It further added that transparency allows stakeholders to gather information that may be critical to uncovering abuses and defending their interests. Therefore, transparent system has clear procedures for public decision making and opens channels of communication between vocational education administrators and stakeholders, and makes a wide range of information accessible.

In the context of this study, the term "accountability" is understood as the process by which people or individuals (including vocational education administrators) are held responsible for executing their powers properly (National Endowment for Democracy, 2009). Accountability can be viewed as the process by which vocational education administrators are answerable for their actions, and are subject to redress when commitment and duties are not met (Transparency International, 2014a; 2014b). The term "accountability" can further be described as the characteristic of vocational education administrators of being open in the clear disclosure of information, rules, plans, processes and actions (Transparency International, 2009; 2014a; 2014b). In this sense, vocational education administrators acting visibly and understandably would promotes accountability and allows people or stakeholders outside a vocational education institution to monitor its work/activity and to take action when something is not as it should be. Integrity on the other hand refers to behaviours and actions consistent with a set of moral or ethical values or standards embraced by people (including vocational education administrators) that create a barrier to corruption (Transparency International, $2014 \mathrm{a} ; 2014 \mathrm{~b})$. Vocational education administrators vested with the power to act in the public interest may be tempted to use their position for personal or private gain. It is based on this assertion that the Transparency International (2017c) saw integrity as the quality of adhering to rules, morals, principles and ethical standards, while operating with honesty and transparency.

The overall purpose of this current study, therefore, is to investigate the extent to which PPCSP can help in ensuring good governance practices for vocational education programme in Federal Universities in South Southern, Nigeria. The specific objectives of the study shall be to:

(a) determine the extent to which PPCSP can ensure that the funds made available for the execution of projects are utilized in an effective and efficient manner.

(b) assess the extent to which PPCSP can ensure the vocational education administrators are transparent in the utilization of funds made available for execution of projects.

(c) determine the extent to which PPCSP can ensure the vocational education administrators are accountable for the funds made available for execution of projects.

(d) assess the extent to which PPCSP can ensure the vocational education administrators are strongly committed to integrity in the use of funds made available for execution of projects.

(e) The following research questions were raised and answered in the study.

(f) To what extent can PPCSP ensure that the funds made available for execution of projects are utilized in an effective and efficient manner?

(g) To what extent can PPCSP ensure the vocational education administrators are transparent in the utilization of funds made available for execution of projects?

(h) To what extent can PPCSP ensure vocational education administrators are accountable for the funds made available for execution of projects?

(i) To what extent can PPCSP ensure the vocational education administrators are strongly committed to integrity in the use of funds made available for execution of projects?

The following null hypotheses were formulated and tested at .05 level of significance. This decision was supported by a quite number of educational research scholars (e.g., Ary, Jacobs, Sorensen, \& Walker, 2014; Fraenkel \& Wallen, 2006; Gay, Mills, \& Airasian, 2009; Mertler \& Charles, 2008; Omorogiuwa, 2006; Uzoagulu, 2011) who suggests that any null hypothesis shall be tested at .05 level of significance.

(a) There is no significant difference between the Mean responses of male and female vocational education lecturers as regards the extent to which PPCSP can ensure that the funds made available for execution of projects are utilized in an effective and efficient manner.

(b) There is no significant difference between the Mean responses of male and female vocational education lecturers as regards the extent to which PPCSP can ensure the vocational education administrators are transparent in the utilization of funds made available for execution of projects. 
(c) There is no significant difference between the Mean responses of male and female vocational education lecturers as regards the extent to which PPCSP can ensure the vocational education administrators are accountable in the utilization of funds made available for execution of projects.

(d) There is no significant difference between the Mean responses of male and female vocational education lecturers as regards the extent to which PPCSP can ensure the vocational education administrators are strongly committed to integrity in the utilization of funds made available for execution of projects.

\section{Methodology}

A descriptive survey research design was used to achieve the specific objectives of the study. The design is primarily a non-experimental quantitative research method (Mitchell \& Jolley, 2007) in which researchers administers some sort of questionnaire to a sample or, in some cases, to entire population of individuals so as to describe their attitudes, opinions, behaviours, experiences, or other characteristics of the population (Creswell, 2005; Ary, Jacobs, \& Sorensen, 2010). It is for this reason that the descriptive survey research design was seen as appropriate for this study in that it determines whether, or the extent to which PPCSP can help in ensuring good governance practices for vocational education programme in federal universities in South-South, Nigeria. The study participants comprised of 154, out of which were 54 Males and 100 Females vocational education lecturers from the Federal Universities, which comprised University of Benin, University of Uyo and University of Calabar, in South-South geopolitical region of Nigeria. The South-South geographical region comprised of 6 States, namely: Edo, Delta, Uyo, Calabar, Bayelsa, and Porthearcort, and were chosen for the study due to the location of the authors' institution. However, only three States, namely: Edo, Uyo and Calabar has Federal Universities that offers vocational education programmes. The authors of the study made no attempt to adopt any sample procedure because the participants were manageable, that is the participants were not too large to cover in the study.

A self-constructed questionnaire was designed and developed from literature that was reviewed as the instrument for the collection of data, titled: "Questionnaire on the Role of Public-Private-Civil Society Partnership in Establishing Good Governance Practices of Vocational Education Programme in Federal Universities in South-South, Nigeria (QRPPCSPEGGPVEPFUSSN)". The instrument was 4-point scale, ranging from 1 (very low extent) to 4 (very high extent). The instrument consists of 44 items, of which 8 items measures PPCSP and effectiveness and efficiency in the utilization of funds, 9 items measures PPCSP and transparency in the utilization of funds, 16 items measures PPCSP and accountability in the utilization of funds, and 11 items measures PPCSP and strong commitment to integrity in the utilization of funds. A panel of 4 lecturers from vocational education and measurement and evaluation verified the content validity of the instrument. The authors analyzed the responses of 25 lecturers, which were not part of the sample, to determine the instrument reliability. The results of the analyzed responses showed that the instrument for data collection was highly reliable, with the Cronbach alpha coefficient value of $\alpha=.90$.

The instrument was further administered on the respondents with the help of two research assistants. The instrument was retrieved as soon as they were completed. The data was analyzed using mean, standard deviations and t-test statistics. The mean was used to answer the research questions; the standard deviations were used to determine the extent to which vocational education lecturers' responses were clustered around or deviated from the mean and the t-test was used to test the null hypotheses at .05 level of significance. The decision rule for the research questions was based on any calculated mean scores equal to, or greater than 2.50 implies that vocational education lecturers agree to a very high extent with the questionnaire items; while any calculated mean scores less than 2.50 implies that vocational education lecturers disagree to a very high extent with the questionnaire items. Furthermore, the standard deviations values between .00 and .96 imply that vocational education lecturers responses are very close, which means that their responses are clustered around the mean. The probability value (p) was used in taking decisions on the null hypotheses. If the p-value is less than or equal to .05 , the null hypotheses is rejected, but if the p-value is greater than .05 , the null hypotheses is not rejected.

\section{Results}

The results of the research were analyzed and presented in Tables 1 to 4 .

\subsection{Research Question 1:}

To what extent can PPCSP ensure that the funds made available for the execution of projects are utilized in an effective and efficient manner?

The analysis of data in respect of research question 1 is shown in Table 1. 
Table 1-Mean and standard deviation of respondents on the extent to which PPCSP ensure effective and efficient utilization of funds for execution of projects

\begin{tabular}{|c|c|c|c|}
\hline $\mathbf{S} / \mathbf{N}$ & To what extent can: & SD & Remarks \\
\hline 1. & PPCSP help in ensuring the optimization of funds for vocational education institutions. 3.72 & .70 & $\mathrm{HE}$ \\
\hline 2. & $\begin{array}{l}\text { PPCSP help in ensuring the employment of the right calibre of manpower for vocational } 3.62 \\
\text { education institutions. }\end{array}$ & .75 & $\mathrm{HE}$ \\
\hline 3. & $\begin{array}{l}\text { PPCSP help in ensuring the procurement of modern infrastructural facilities for } 3.59 \\
\text { vocational education institutions. }\end{array}$ & .77 & $\mathrm{HE}$ \\
\hline 4. & $\begin{array}{l}\text { PPCSP help in ensuring the renewal and development of curriculum for vocational } 3.36 \\
\text { education institutions. }\end{array}$ & .86 & $\mathrm{HE}$ \\
\hline 5. & $\begin{array}{l}\text { PPCSP help in ensuring the optimization of quality resources for the execution of } 3.32 \\
\text { projects. }\end{array}$ & .74 & $\mathrm{HE}$ \\
\hline 6. & $\begin{array}{l}\text { PPCSP help in ensuring that students are equip with the requisite skills to become } 3.27 \\
\text { artisans and craftsmen for commerce and industry. }\end{array}$ & .78 & $\mathrm{HE}$ \\
\hline 7. & $\begin{array}{l}\text { PPCSP help in ensuring that the vocational education programmes are producing skilled } 3.32 \\
\text { and competent graduates that employers' value. }\end{array}$ & .76 & $\mathrm{HE}$ \\
\hline \multirow[t]{2}{*}{8.} & $\begin{array}{l}\text { PPCSP help in ensuring that vocational education students are equip with the requisite } 3.19 \\
\text { skills to engage in lifelong learning task. }\end{array}$ & .74 & $\mathrm{HE}$ \\
\hline & Total & .63 & $\mathrm{HE}$ \\
\hline
\end{tabular}

The results of the data presented in Table 1 showed that 8 items, with serial number $1,2,3,4,5,6,7$, and 8 had the mean scores that ranged from 3.19 to 3.72 , and the corresponding Standard Deviations values ranged from .74 to .86 respectively. The Mean scores simply imply that to a very high extent PPCSP can help in ensuring the funds made available for projects execution are utilized in an effective and efficient manner. The corresponding standard deviations values imply that vocational education lecturers' responses as regards the extent to which PPCSP can ensure the funds made available for execution of projects are utilized in an effective and efficient manner are very close irrespective of their gender differences.

\subsection{Research Question 2:}

To what extent can PPCSP ensure that the vocational education administrators are transparent in the utilization of funds made available for execution of projects?

The analysis of data in respect of research question 2 is shown in Table 2.

Table 2- Mean and standard deviation of respondents on the extent to which PPCSP ensure transparency in the utilization of funds for execution of projects

\begin{tabular}{|c|c|c|c|c|}
\hline $\mathbf{S} / \mathbf{N}$ & To what extent can: & $\bar{x}$ & SD & Remarks \\
\hline 1. & $\begin{array}{l}\text { PPCSP help in ensuring that the information conveyed through meetings or documentations are } \\
\text { available to the general public. }\end{array}$ & 3.43 & .77 & $\mathrm{HE}$ \\
\hline 2. & $\begin{array}{l}\text { PPCSP help in ensuring the existence of offline public access to information or the information } \\
\text { disclosure. }\end{array}$ & 3.32 & .79 & $\mathrm{HE}$ \\
\hline 3. & $\begin{array}{l}\text { PPCSP help in ensuring that information are available freely online, not on request by the general } \\
\text { public. }\end{array}$ & 3.35 & .78 & HE \\
\hline 4. & $\begin{array}{l}\text { PPCSP help in ensuring that information available online or offline for public perusal are accurate } \\
\text { and complete. }\end{array}$ & 3.19 & .72 & $\mathrm{HE}$ \\
\hline 5. & $\begin{array}{l}\text { PPCSP help in ensuring that information available online or offline for public perusal are coherent } \\
\text { and understandable. }\end{array}$ & 3.16 & .72 & $\mathrm{HE}$ \\
\hline 6. & $\begin{array}{l}\text { PPCSP help in ensuring that information available online or offline for public perusal are timely } \\
\text { and reliable without a certain timeframe or deadline. }\end{array}$ & 3.27 & .78 & $\mathrm{HE}$ \\
\hline 7. & $\begin{array}{l}\text { PPCSP help in ensuring that information available online or offline for public perusal are } \\
\text { regularly updated. }\end{array}$ & 3.31 & .80 & $\mathrm{HE}$ \\
\hline 8. & $\begin{array}{l}\text { PPCSP help in ensuring that information available online or offline for public perusal do not exist } \\
\text { within certain timeframe and are without deadlines. }\end{array}$ & 3.29 & .78 & $\mathrm{HE}$ \\
\hline 9. & $\begin{array}{l}\text { PPCSP help in ensuring that information concerning projects execution, such as appointment, } \\
\text { disbursement and implementation are unveiled to the general public. }\end{array}$ & 3.27 & .80 & $\mathrm{HE}$ \\
\hline & Total & 3.29 & .59 & $\mathrm{HE}$ \\
\hline
\end{tabular}


Table 2 showed that 9 items, with serial number 1, 2, 3, 4, 5, 6, 7, 8, and 9 had the mean scores that ranged from 3.16 to 3.43 , and the corresponding Standard Deviations values ranged from .72 to .80 respectively. The Mean scores simply imply that to a very high extent PPCSP can ensure that the vocational education administrators are transparent in the utilization of funds made available for execution of projects. The corresponding standard deviations values imply that the vocational education lecturers' responses as regards the extent to which PPCSP can ensure that the vocational education administrators are transparent in the utilization of funds made available for execution of projects are very close irrespective of their gender differences.

\subsection{Research Question 3:}

To what extent can PPCSP ensure that the vocational education administrators are accountable for the funds made available for the execution of projects?

The analysis of data in respect of research question 3 is shown in Table 3.

Table 3: Mean and standard deviation of respondents on the extent to which PPCSP ensure accountability in the utilization of funds for execution of projects

\begin{tabular}{|c|c|c|c|c|}
\hline $\mathbf{S} / \mathbf{N}$ & To what extent can: & $\bar{x}$ & SD & Remarks \\
\hline 1. & $\begin{array}{l}\text { PPCSP help in ensuring the disbursement of funds for execution of projects are documented often } \\
\text { in financial reports. }\end{array}$ & & .75 & $\mathrm{HE}$ \\
\hline 2. & $\begin{array}{l}\text { PPCSP help in ensuring the disbursement of funds for staff employment and appointments are } \\
\text { documented often in financial reports. }\end{array}$ & 3.27 & .76 & $\mathrm{HE}$ \\
\hline 3. & $\begin{array}{l}\text { PPCSP help in ensuring the disbursement of funds for research engagement by members of staff } \\
\text { are documented often in financial reports. }\end{array}$ & 3.24 & .82 & $\mathrm{HE}$ \\
\hline 4. & $\begin{array}{l}\text { PPCSP help in ensuring disbursement of funds for organizing and attending seminars, workshops } \\
\text { or conferences are documented often in financial reports. }\end{array}$ & 3.65 & .73 & $\mathrm{HE}$ \\
\hline 5. & $\begin{array}{l}\text { PPCSP help in ensuring disbursement of funds for procurement of facilities and equipment are } \\
\text { documented often in financial reports. }\end{array}$ & 3.55 & .74 & $\mathrm{HE}$ \\
\hline 6. & $\begin{array}{l}\text { PPCSP help in ensuring disbursement of funds for erecting befitting buildings are documented } \\
\text { often in financial reports. }\end{array}$ & 3.37 & .75 & $\mathrm{HE}$ \\
\hline 7. & $\begin{array}{l}\text { PPCSP help in ensuring disbursement of funds for development and renewal of curriculum are } \\
\text { documented often in financial reports. }\end{array}$ & 3.34 & .76 & $\mathrm{HE}$ \\
\hline 8. & $\begin{array}{l}\text { PPCSP help in ensuring disbursement of funds for accreditation purposes are documented often } \\
\text { in financial reports. }\end{array}$ & 3.23 & .75 & $\mathrm{HE}$ \\
\hline 9. & $\begin{array}{l}\text { PPCSP help in ensuring disbursement of funds for monitoring and evaluation of activities are } \\
\text { documented often in financial reports. }\end{array}$ & 3.30 & .75 & $\mathrm{HE}$ \\
\hline 10. & $\begin{array}{l}\text { PPCSP help in ensuring that there are mechanisms in place to vet the validity and reliability of } \\
\text { financial reports. }\end{array}$ & 3.31 & .80 & $\mathrm{HE}$ \\
\hline 11 & $\begin{array}{l}\text { PPCSP help in ensuring that audits of funds disbursed for any activity, such as, those identified } \\
\text { above are conducted frequently. }\end{array}$ & 3.31 & .74 & $\mathrm{HE}$ \\
\hline 12 & $\begin{array}{l}\text { PPCSP help in ensuring that results of audits of funds disbursed for activities, such as, those } \\
\text { identified above are available to the general public. }\end{array}$ & 3.29 & .80 & $\mathrm{HE}$ \\
\hline 13 & $\begin{array}{l}\text { PPCSP help in ensuring that decisions and procedures to disbursed funds for any activity are } \\
\text { subject to timely and enforceable review. }\end{array}$ & 3.32 & .76 & $\mathrm{HE}$ \\
\hline 14 & $\begin{array}{l}\text { PPCSP help in ensuring that decisions and procedures to disbursed funds for any activity are } \\
\text { publicly available. }\end{array}$ & 3.26 & .80 & $\mathrm{HE}$ \\
\hline 15 & $\begin{array}{l}\text { PPCSP help in ensuring that there are policies and procedures which requires sanctions and } \\
\text { punishments for any corrupt behaviour been exhibited at all levels of project implementation. }\end{array}$ & 3.32 & .72 & $\mathrm{HE}$ \\
\hline \multirow[t]{2}{*}{16} & $\begin{array}{l}\text { PPCSP help in ensuring that information on the policies and procedures about sanctions and } \\
\text { punishments are publicly available. }\end{array}$ & 3.18 & .78 & $\mathrm{HE}$ \\
\hline & Total & 3.33 & .58 & $\mathrm{HE}$ \\
\hline
\end{tabular}

Table 3 showed that 16 items, with serial number 1, 2, 3, 4, 5, 6, 7, 8, 9, 10,11,12, 13, 14, 15, and 16 had the mean scores that ranged from 3.18 to 3.65 , and the corresponding Standard Deviations values ranged from .72 to .80 respectively. The Mean scores simply imply that to a very high extent PPCSP can ensure that vocational education administrators are accountable for the funds made available for execution of projects. The corresponding standard deviations values imply that the vocational education lecturers' responses as regards the extent to which PPCSP can ensure that the vocational education administrators are accountable for the funds made available for execution of projects are very close irrespective of their gender differences. 


\subsection{Research Question 4:}

To what extent can PPCSP ensure that the vocational education administrators are strongly committed to integrity in the utilization of funds made available for the execution of projects?

The analysis of data in respect of research question 4 is shown in Table 4.

Table 4: Mean and standard deviation of respondents on the extent to which PPCSP ensure strong commitment to integrity in the utilization of funds for execution of projects

\begin{tabular}{|c|c|c|c|c|}
\hline $\mathbf{S} / \mathbf{N}$ & To what extent can: & $\bar{x}$ & SD & Remarks \\
\hline 1. & $\begin{array}{l}\text { PPCSP help in ensuring that there are comprehensive codes of conduct written in the guiding } \\
\text { documents of funds disbursed for projects execution. }\end{array}$ & 3.55 & .71 & $\mathrm{HE}$ \\
\hline 2. & $\begin{array}{l}\text { PPCSP help in ensuring that comprehensive codes of conduct written in the guiding documents } \\
\text { of funds disbursement are publicly available. }\end{array}$ & 3.40 & .72 & HE \\
\hline 3. & $\begin{array}{l}\text { PPCSP help in ensuring that comprehensive code of conduct written in the guiding documents of } \\
\text { funds disbursed for projects execution are enforced. }\end{array}$ & 3.36 & .81 & HE \\
\hline 4. & $\begin{array}{l}\text { PPCSP help in ensuring that employed or appointed staff comport themselves according to widely } \\
\text { accepted standards of professional conduct. }\end{array}$ & 3.34 & .76 & $\mathrm{HE}$ \\
\hline 5. & $\begin{array}{l}\text { PPCSP help in ensuring that there are sanctions and punishments for non-compliance to the codes } \\
\text { of conduct written in the guiding documents. }\end{array}$ & 3.23 & .82 & $\mathrm{HE}$ \\
\hline 6. & $\begin{array}{l}\text { PPCSP help in ensuring that integrity screening are conducted or background are checked among } \\
\text { staff members before embarking on any project. }\end{array}$ & 3.26 & .76 & $\mathrm{HE}$ \\
\hline 7. & $\begin{array}{l}\text { PPCSP help in ensuring that integrity screening or background checks among staff members are } \\
\text { conducted by internal and external bodies before embarking on any project. }\end{array}$ & 3.33 & .82 & $\mathrm{HE}$ \\
\hline 8. & $\begin{array}{l}\text { PPCSP help in ensuring that screening or background of staff members covers (their education, } \\
\text { employment history, credentials, criminal records, sanctions by relevant regulatory bodies, and } \\
\text { more) before embarking on any project. }\end{array}$ & 3.31 & .75 & $\mathrm{HE}$ \\
\hline 9. & $\begin{array}{l}\text { PPCSP help in ensuring that all staff members are trained on codes of professional conduct or } \\
\text { integrity as part of their professional orientation. }\end{array}$ & 3.30 & .75 & $\mathrm{HE}$ \\
\hline 10. & $\begin{array}{l}\text { PPCSP help in ensuring that all staff and appointees attend classes or briefings explaining in detail } \\
\text { the respective codes of conduct they are subjected to. }\end{array}$ & 3.24 & .78 & $\mathrm{HE}$ \\
\hline \multirow[t]{2}{*}{11.} & $\begin{array}{l}\text { PPCSP help in ensuring that there are sanctions and punishments for staff and appointees who do } \\
\text { not comply or attend classes or briefings. }\end{array}$ & 3.25 & .84 & $\mathrm{HE}$ \\
\hline & Total & 3.32 & .60 & $\mathrm{HE}$ \\
\hline
\end{tabular}

Table 4 showed that 11 items, with serial number 1, 2, 3, 4, 5, 5, 6, 7, 8, 9, 10, and 11 had the mean scores that ranged from 2.97 to 3.04, and the corresponding Standard Deviations values ranged from .53 to .58 respectively. The Mean scores simply imply that to a very high extent PPCSP can ensure that the vocational education administrators are strongly committed to integrity in the utilization of funds made available for execution of projects. The corresponding standard deviations values imply that the vocational education lecturers' responses as regards the extent to which PPCSP can ensure the vocational education administrators are strongly committed to integrity in the utilization of funds for execution of projects.

\section{Testing the Null Hypotheses}

The data analysis for testing the hypotheses was carried out using the t-test statistic. The results are presented in Tables 5 to 8 .

\subsection{Hypothesis 1:}

There is no significant difference between the Mean responses of male and female vocational education lecturers regarding the extent to which PPCSP can ensure that the funds made available for the execution of projects are utilized in an effective and efficient manner.

The test of hypothesis 1 is shown in Table 5. 
Table 5- t-test analysis of the difference between male and female lecturers as regards the extent to which PPCSP can ensure the effective and efficient utilization of funds for execution of projects

\begin{tabular}{|c|c|c|c|c|c|c|c|c|}
\hline Variables & Categories & $\mathbf{N}$ & $\bar{x}$ & SD & df & $T$ & $p$ & Decision \\
\hline \multirow{4}{*}{$\begin{array}{l}\text { Extent of PPCSP in ensuring the } \\
\text { execution of projects in an } \\
\text { effective and efficient manner. }\end{array}$} & Male & 54 & 3.44 & .62 & & & & \\
\hline & & & & & 152 & .22 & .83 & Don't reject $\mathrm{H} 0$ \\
\hline & Female & 100 & 3.42 & .64 & & & & \\
\hline & Total & 154 & & & & & & \\
\hline
\end{tabular}

Source: Field Study, 2018

Table 5 showed that the aggregate Mean responses of male and female lecturers as regards the extent to which PPCSP can ensure that the funds made available for execution of projects are utilized in an effective and efficient manner are 3.44 and 3.42, while the corresponding standard deviations values are .62 and .64 respectively. The Table also showed that the $\mathrm{t}$-value is .22 at $\mathrm{df}$ of 152 , while the p-value (.83) is greater than the significant alpha value (.05); therefore, the null hypothesis is not rejected. Hence, male lecturers do not differ significantly from their female counterparts as regards their Mean responses on the extent to which PPCSP can ensure that the funds made available for the execution of projects are utilized in an effective and efficient manner.

\subsection{Hypothesis 2:}

There is no significant difference between the Mean responses of male and female vocational education lecturers as regards the extent to which PPCSP can ensure that the vocational education administrators are transparent in the utilization of funds made available for execution of projects.

The test of hypothesis 2 is shown in Table 6 .

Table 6- t-test analysis of the difference between male and female lecturers as regards the extent to which PPCSP can ensure transparency in the utilization of funds for execution of projects

\begin{tabular}{|c|c|c|c|c|c|c|c|c|}
\hline Variables & Categories & $\mathbf{N}$ & $\bar{x}$ & SD & df & $t$ & $p$ & Decision \\
\hline \multirow{4}{*}{$\begin{array}{l}\text { Extent of PPCSP in ensuring the } \\
\text { transparent utilization of funds for } \\
\text { execution of projects. }\end{array}$} & Male & 54 & 3.27 & .49 & & & & \\
\hline & & & & & 152 & .32 & .75 & Don't reject $\mathrm{H} 0$ \\
\hline & Female & 100 & 3.30 & .69 & & & & \\
\hline & Total & 154 & & & & & & \\
\hline
\end{tabular}

Source: Field Study, 2018

Table 6 showed that the aggregate Mean responses of male and female lecturers as regards the extent to which PPCSP can ensure that the vocational education administrators are transparent in the utilization of funds made available for execution of projects are 3.27 and 3.30, while the corresponding standard deviations values are .49 and .69 respectively. The Table also showed that the $\mathrm{t}$-value is .32 at $\mathrm{df}$ of 152 , while the p-value (.75) is greater than the significant alpha value (.05); therefore, the null hypothesis is not rejected. Hence, male lecturers do not differ significantly from their female counterparts as regards their Mean responses on the extent to which PPCSP can ensure that the vocational education administrators are transparent in the utilization of funds made available for execution of projects.

\subsection{Hypothesis 3:}

There is no significant difference between the Mean responses of male and female vocational education lecturers as regards the extent to which PPCSP can ensure that the vocational education administrators are accountable for the funds made available for execution of projects.

The test of hypothesis 3 is shown in Table 7.

Table 7- t-test analysis of the difference between male and female lecturers as regards the extent to which PPCSP can ensure accountability in the utilization of funds for execution of projects

\begin{tabular}{|c|c|c|c|c|c|c|c|c|}
\hline Variables & Categories & $\mathbf{N}$ & $\bar{x}$ & SD & df & $t$ & $p$ & Decision \\
\hline \multirow{4}{*}{$\begin{array}{l}\text { Extent of PPCSP in ensuring the } \\
\text { accountability of funds for } \\
\text { execution of projects. }\end{array}$} & Male & 54 & 3.31 & .53 & & & & \\
\hline & & & & & 152 & .38 & .71 & Don't reject $\mathrm{H} 0$ \\
\hline & Female & 100 & 3.35 & .63 & & & & \\
\hline & Total & 154 & & & & & & \\
\hline
\end{tabular}


Table 7 showed that the aggregate Mean responses of male and female lecturers as regards the extent to which PPCSP can ensure that the vocational education administrators are accountable for the funds made available for execution of projects are 3.31 and 3.35 , while the corresponding standard deviations values are .53 and .63 respectively. The Table also showed that the t-value is .38 at $\mathrm{df}$ of 152 , while the p-value (.71) is greater than the significant alpha value (.05); therefore, the null hypothesis is not rejected. Hence, male lecturers do not differ significantly from their female counterparts as regards their Mean responses on the extent to which PPCSP can ensure that the vocational education administrators are accountable for the utilization of funds made available for execution of projects.

\subsection{Hypothesis 4:}

There is no significant difference between the Mean responses of male and female vocational education lecturers as regards the extent to which PPCSP can ensure that the vocational education administrators are strongly committed to integrity in the utilization of funds made available for execution of projects.

The test of hypothesis 4 is shown in Table 8 .

Table 8- t-test analysis of the difference between male and female lecturers as regards the extent to which PPCSP can ensure strong commitment to integrity in the utilization of funds for execution of projects

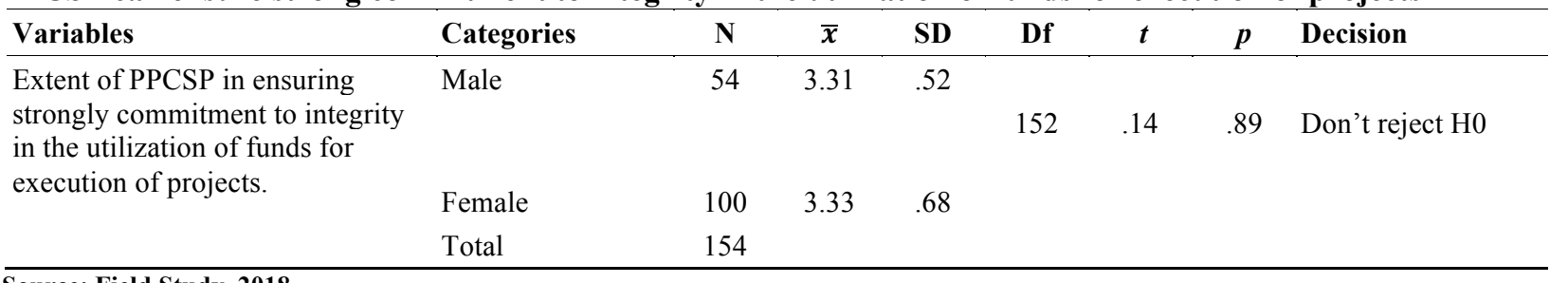

Source: Field Study, 2018

Table 8 showed that the aggregate Mean responses of male and female lecturers as regards the extent to which PPCSP can ensure that vocational education administrators are strongly committed to integrity in the utilization of funds made available for execution of projects are 3.31 and 3.33, while the corresponding standard deviations values are .52 and .68 respectively. The Table also showed that the t-value is .14 at $\mathrm{df}$ of 152 , while the p-value (.89) is greater than the significant alpha value (.05); therefore, the null hypothesis is not rejected. Hence, male lecturers do not differ significantly from their female counterparts as regards their Mean responses on the extent to which PPCSP can ensure that the vocational education administrators are strongly committed to integrity in the utilization of funds made available for execution of projects.

\section{Discussion}

Using the descriptive statistics of mean and standard deviations, the analysis of research question 1 revealed that to a very high extent PPCSP can help to ensure that the funds made available for projects execution are utilized in an effective and efficient manner. This finding conforms to the submission of Fennell (2007) and World Bank (2009) that the argument in favour of PPCSP in education was to bring in the management practices of the private sector into public sector so as to improve competitiveness and increase efficiency. Fennell (2007) further contended that the understanding behind the introduction of PPCSP was to make public expenditure more effective and efficient, and in some cases, would attract the financial investment from the private sector. Taken together, Savas (2000) stated that one of the main reasons advanced for the governments to enter into contractual PPCSP include to improve the quality of spending by lifting the efficiency and the effectiveness of quality service delivery and by allowing better targeting of spending or investment. This implies that PPCSP would help to foster profit-making as a beneficial feature to ensure better and more effective/efficient production of quality services in vocational education.

The test of corresponding hypothesis to research question 1 revealed that there was no significant difference between the Mean responses of male and female vocational education lecturers as regards the extent to which PPCSP can ensure that the funds made available for the execution of projects are utilized in an effective and efficient manner. This finding implies that male and female lecturers of vocational education are both in agreement that PPCSP can ensure the funds made available for the execution of projects are utilized in effective and efficient manner. This finding agrees with the study conducted by Edokpolor and Imafidon (2017) who found that PPCSP will assist in improving effective management of vocational education programme, as it may help to increase greater utilization of funds so that qualified personnel, better facilities and quality curriculum can be made available. The World Bank (2009) claims that PPP is likely to increase effectiveness and efficiency in the delivery of education and, of course, would help in channelling additional resources to the management of education.

Using the descriptive statistics of mean and standard deviations, the analysis of research question 2 revealed that to a very high extent PPCSP can ensure that the vocational education administrators are transparent in the utilization of funds made available for execution of projects. This finding is consistent with the assertion of Savas (2000) that one of 
the main reasons advanced for the governments, or the public-sector organizations to enter into contractual PPCSP was to increase transparency of government spending by making the cost of services more visible to all.

The test of corresponding hypothesis to research question 2 revealed that there was no significant difference between the Mean responses of male and female vocational education lecturers as regards the extent to which PPCSP can ensure vocational education administrators are transparent in the utilization of funds made available for the execution of projects. This finding implies that male and female lecturers of vocational education are both in agreement that PPCSP can promote transparency in the utilization of funds made available for the execution of projects. This finding supports the assertion of Wang (1999) who argued that partnerships among public, private and civil society organizations is geared toward improving financing and provision of existing services with an emphasis directed on system transparency and accountability. LaRocque (2008) also pointed out that well-designed multiple stakeholder partnerships can make the utilization of financial resources made available for the execution of education projects more transparent.

Using the descriptive statistics of mean and standard deviations, the analysis of research question 3 revealed that to a very high extent PPCSP can ensure that the vocational education administrators are accountable for the funds made available for the execution of projects. This result is in line with the assertion of Transparency International (2014a, 2017a) who recommends that putting PPCSP in place would help to ensure the management and increase the availability of information to ensure that the committed funds are judiciously spent and accounted for.

The test of corresponding hypothesis to research question 3 revealed that there was no significant difference between the Mean responses of male and female vocational education lecturers as regards the extent to which PPCSP can ensure vocational education administrators are accountable for funds made available for the execution of projects. This finding implies that male and female lecturers of vocational education are both in agreement that PPCSP can promote accountability of funds made available for the execution of projects. This finding conforms to the assertion of Gauri and Vawda (2004) who opined that partnerships among public, private and other sector stakeholders aims at promoting improvements in the financing of educational services with an emphasis directed on system accountability. In addition, Finn and Vanourek (2007) argues that partnerships among public, private and civil society sector stakeholders can help promote dual accountability both to the private (parents) and to the public (government) entities.

Using the descriptive statistics of mean and standard deviations, the analysis of research question 4 revealed that to a very high extent PPCSP can ensure that the vocational education administrators are strongly committed to integrity in the use of funds made available for the execution of projects. This result is in line with the assertion of the Transparency International (2014b; 2017a) and ETF (2011a) who asserted that putting in place strong PPCSP mechanisms would help to increase the clarity and openness of how funds for vocational education are spent.

The test of corresponding hypothesis to research question 4 revealed that there was no significant difference between the Mean responses of male and female vocational education lecturers regarding the extent to which PPCSP can ensure vocational education administrators are strongly committed to integrity in the use of funds made available for the execution of projects. This finding implies that male and female lecturers of vocational education are both in agreement that PPCSP can promote strong commitment to integrity in the use of funds made available for the execution of projects. This finding agrees with the assertion of LaRocque (2008) who argues that well-designed partnerships among all major stakeholders of education can help to reduce the high level of corrupt practices (e.g., immoral and unethical standards) in the education sector. Similarly, Fennell (2007) reiterates that the argument from both male and female educators as regards the introduction of partnerships was to bring in management practices (e.g., financial integrity) of private sector into the public sector so as to improve educational effectiveness and efficiency.

\section{Conclusion}

This study focuses on the extent to which PPCSP can help in ensuring good governance practices for vocational education programme in Federal Universities in South Southern, Nigeria. This study was motivated as a result of the mismanagement of funds, corrupt and fraudulent practices that are currently hindering the realization of the broad goals of vocational education programme. The study therefore found that to a very high extent PPCSP can help in establishing good governance practices (specifically, effectiveness and efficiency, transparency, accountability and integrity) in the utilization of funds for the execution of projects by the vocational education administrators. When the hypotheses were analysed, the study found no significant difference in the mean responses of male and female vocational education lecturers as regards the extent to which PPCSP can help in establishing good governance practices in the utilization of funds for the execution of projects. This study therefore concludes that PPCSP has an important role in promoting good governance practices (e.g., effectiveness and efficiency, transparency, accountability and integrity) in the utilization of funds for the execution of projects in vocational education programme, especially in Nigeria and other parts of the world. This study as a result of the findings and the conclusion arising therefrom has contributed to the strategic management theory and practice in a number of ways.

\section{Limitations}

As rightly pointed out by scholars and researchers, there is no study without limitations. Thus, this extant study has some obvious limitations to address. However, the study has provided empirical evidence as regards the role of PPCSP in 
ensuring good governance practices of vocational education. First, due to the data that were collected via a nonexperimental procedure (i.e., a cross-sectional survey or simply put as a descriptive survey research design), causal inference could not be made in the study. The authors, therefore, recommend that longitudinal and experimental study should be embarked on by researchers to improve on existing findings or provide better results. Second, due to the sample size of the participants $(N=154)$, which was drawn from just a single institution (federal) university in South-South geopolitical zone of Nigeria, caution should be exercise in generalizing the results of the study. Therefore, the authors recommend that future research should aim at considering the inclusion of proportionally representative samples that cut across all geopolitical zones (e.g., South-East, South-West, North-East, North-West, and North-Central) to ensure equal or balanced representation of samples from all federal universities in Nigeria. Third, due to the homogenous nature of participants which involves the vocational education lecturers only, caution should be exercised in generalizing results to lecturers in other academic fields. Therefore, the authors recommend that researchers should embark on further study, which include other categories of lecturers (or participants) from other educationally or humanities-oriented disciplines.

\section{Implications}

As pointed out in the introduction, much focus has not been placed on studying the extent to which PPCSP can help in establishing good governance practices of vocational education, especially in Nigeria. The results of this study, therefore, have implications for the educational stakeholders and researchers regarding the role of PPCSP in ensuring good governance practices of vocational education. First, the study found that the PPCSP to a very high extent can help in ensuring the funds made available for projects execution are utilized in an effective and efficient manner. It would thus be very helpful for all the major stakeholders of vocational education to collaborate in order to ensure that the funds made available for projects execution are utilized in an effective and efficient manner. Second, the study found that the PPCSP to a very high extent can help in ensuring that vocational education administrators are transparent in the use of funds made available for projects execution. It would thus be very helpful for all major stakeholders of vocational education to collaborate in order to ensure that vocational education administrators are transparent in the use of funds made available for projects execution. Third, the study found that PPCSP to a very high extent can help in ensuring that vocational education administrators are accountable for the funds made available for projects execution. It would thus be very helpful for all the major stakeholders of vocational education to collaborate in order to ensure that the vocational education administrators are accountable for the funds made available for execution of projects. Finally, the study found that PPCSP to a very high extent can help in ensuring that vocational education administrators are strongly committed to integrity in the use of funds made available for execution of projects. It would thus be very helpful for all the major stakeholders of vocational education to collaborate in order to ensure that vocational education administrators are strongly committed to integrity in the use of funds made available for execution of projects. These recommendations, if adequately implemented, would help in realizing the broad goals of vocational education programme. As such, the realization of these broad goals via PPCSP would assist in equipping students with the skills to participate in professional careers upon graduation.

\section{References}

Abrams, P., Borrini-Feyerabend, G., Gardner, J., \& Heylings, P. (2003). Evaluating governance: A handbook to accompany a participatory process for a protected area. Retrieved from at https://portals.iucn.org/library/sites/library/files/documents/Rep-2003-022.pdf

Adewuyi, J. O., \& Okemakinde, T. (2013). Higher education financing in Nigeria: Issues and trends. International Journal of Educational Administration and Policy Studies, 5 (7), 121-127. doi: 10.5897/IJEAPS12.033

Akpomudjere, O. (2015). Technical vocational education and training (TVET) and private sector partnership for national development. Nigerian Vocational Association Journal, 20, 2. 155-166.

Ary, D., Jacobs, L. C., \& Sorensen, C. (2010). Introduction to research in education ( $8^{\text {th }}$ ed.). United States: Wadsworth, Cengage Learning. Retrieved from www.modares.ac.ir/uploads/Agr.Oth.Lib.12.pdf.

Ary, D., Jacobs, L. C., Sorensen, C. K., \& Walker, D. A. (2014). Introduction to research in education ( $9^{\text {th }}$ ed.). United States: Wadsworth, Cengage Learning.

Aurora, A., Teixeira, C., \& Luís, G. (2015). Corruption and FDI: Does the use of distinct proxies for corruption matter. Journal of African Business, 16 (1-2), 159-179. doi: 10.1080/15228916.2015.1027881

Ball, S. J., \& Youdell, D. (2007). Hidden privatization in public education. Paper Presented in the $5^{\text {th }}$ World Congress of the Education International. $\quad$ Retrieved from https://pages.eiie.org/quadrennialreport/2007/upload/content_trs__images/630/Hidden_privatisation-EN.pdf

Blom, A., \& Cheong, J. (2010). Governance of technical education in India: Key issues, principles, and case studies. Washington, DC: The World Bank Group. http://siteresources.worldbank.org/EDUCATION/Resources/278200-

1099079877269/Governance_technical_edu_India.pdf 
British Council (2017). The role of TVET governance at sub-national levels. Simon Perryman and John Perryman of Perryman, Yeandle and Associates Ltdr from https://www.britishcouncil.org/sites/default/files/the_role_of_tvet_governance_at_sub-national_levels_-_june_2017.pdf Cedefop (2011a). Glossary: Quality in education and training. Publications Office of the European Union, Luxembourg. Retrieved from http://www.cedefop.europa.eu/files/4106_en.pdf

Centre for European Studies (2006). Public-private partnerships and the national experiences in the European Union: Study requested by the European Parliament on Internal Market and Consumer Protection. Retrieved from http://www.europarl.europa.eu/comparl/imco/studies/0602.pdf.

Creswell, J. W. (2005). Educational research: Planning, conducting, and evaluating quantitative and qualitative research ( $2^{\text {nd }}$ ed.). New Jersey: Upper Saddle River. Merrill/Prentice Hall. Retrieved from http://basu.nahad.ir/uploads/creswell.pdf

Edokpolor, E. J. (2018a). The use of students-centred methods in the teaching of business studies in junior secondary schools. Journal of Education in Developing Areas (JEDA), 26, 1. 23-31.

Edokpolor, E. J. (2018b). Systems approach in developing creative thinking and innovative capabilities for lifelong learning among TVET students in Federal Universities, South-South, Nigeria. International Journal of Educational Development, 21, 1. 1-15.

Edokpolor, E. J. (2018c). Influence of self-efficacy antecedents on career decision-making among business education students in federal universities in south southern, Nigeria. Ibadan Journal of Educational Studies (IJES), 15, 2. 95-106.

Edokpolor, J. E., \& Imafidon, A. (2017). Effectiveness of public-private partnership in the management of technical and vocational education and training. Education Policy, Management and Quality, 9 (1), 20-32. Retrieved from http://oaji.net/articles/2017/513-1505287935.pdf

Edokpolor, E. J., \& Muritala, A. T. (2018). Developing entrepreneurial skills and lifelong learning for career self-efficacy among business education students in federal universities in south-south, Nigeria. International Journal of Educational Benchmark, 9, 2. 61-77.

Edokpolor, J. E., \& Oduma, C. (2018). Repositioning business education programme for post-oil boom economy. International Journal of Vocational and Technical Education, 10 (2), 14-23. doi: 10.5897/IJVTE2017.0235

Edokpolor, E. J., \& Owenvbiugie, R. O. (2017). Technical and vocational education and training skills: An antidote for job creation and sustainable development of Nigerian economy. Problems of Education in the $21^{\text {st }}$ Century, 75 (6), 535 549. Retrieved from http://www.scientiasocialis.lt/pec/node/files/pdf/vol75/535-549.Edokpolor_Vol.75-6_PEC.pdf

Education International (2009). Public-private partnerships in education. Retrieved from http.//download.eiie.org/Docs/WebDepot/200909PulicationPublic-Private-Partnership-in- Education_en.pdf.

Egbri, J. N., \& Chukwuedo, S. O. (2014). Re-engineering technical vocational education and training (TVET) in Nigeria through school-industry collaboration for capacity building. Nigerian Vocational Association Journal (NVAJ), 18, 1. 7482.

Ekponyong, L. E. (2011). Foundations of technical vocational education: Evolution and practice for Nigerian students in TVE and adult education, policy makers \& practioners. Benin City: Ambik Press.

European Training Foundation (ETF) (2011a). The Torino Process: Evidence-based policy making for vocational education and training. ETF, Turin.

European Training Foundation (ETF) (2013). Good multilevel governance for vocational education and training. Luxembourg: Office for Official Publications. $\quad$ Retrieved https://www.etf.europa.eu/sites/default/files/m/5C0302B17E20986CC1257C0B0049E331_Multilevel\%20governance\% 20x\%20VET.pdf

European Training Foundation (ETF) (2014). Mapping vocational education and training governance in Libya. Luxembourg: Office for Official Publications. https://www.etf.europa.eu/sites/default/files/m/424678AAE60C0A3BC1257D93005BCFFB_Libya_mapping\%20VET $\% 20$ governance.pdf

Fennell, S. (2007). Tilting at windmills: Public-private partnerships in Indian education today. Contemporary Education Dialogue, 4 (2), 193-216. doi: 10.1177/0973184913411142

Finn, C. E., \& Vanourek, G. (2007). Lessons from the U.S. experience with charter schools. In H. A. Patrinos \& S. Sosale (Eds.). Mobilizing the private sector for public education: A view from the trenches (11-30). Washington DC: World Bank. 
Fraenkel, J. R., \& Wallen, N. E. (2006). How to design and evaluate research in education (6 ${ }^{\text {th }}$ ed.). Boston: McGrawHill.

Gauri, V., \& Vawda, A. (2004). Vouchers for basic education in developing economies: A principal agent perspective. World Bank Research Observer, 19, 2. 259-280.

Gay, L. R., Mills, G. E., \& Airasian, P. (2009). Educational research: Competencies for analysis and applications $\left(9^{\text {th }}\right.$ ed.). Upper Saddle River, New Jersey: Merrill.

Hammed, A.A. (2018). Corruption, political instability and development Nexus in Africa: A call for sequential policies reforms. (Munich personal RePEc archive) MPRA paper no. 8527. Retrieved from https://mpra.ub.unimuenchen.de/85277/.

Kitchen, H., Fordham, E., Hendarson, K., Looney, A., \& Maghnouj, S. (2017). OECD reviews of evaluation and assessment in education. Retrieved from https://www.unicef.org/romania/OECD_Reviews_en_pt_web.pdf

LaRocque, N. (2008). Public-private partnerships in basic education: An international review. Retrieved from https://olc.worldbank.org/sites/default/files/CfBT_LaRocque_PPPs\%20in\%20Basic\%20Education\%20An\%20Internati onal\%20Review_0.pdf

McLean, R., \& Wilson, D. (2009). International handbook of education for the changing world of work: Bridging academic and vocational learning. International Library of Technical and Vocational Education and Training, 1, 6.

Mertler, C. A., \& Charles, C. M. (2008). Introduction to educational research (6 ${ }^{\text {th }}$ ed.). Boston, MA: Pearson Education, Inc.

Mitchell, M. L., \& Jolley, J. M. (2007). Research design explained (6 ${ }^{\text {th }}$ ed.). Belmont, CA: Thompson Wadsworth. Retrieved from http//www.steporebook.com/book/research-design-explained-6th-edition-96693-pdf.html.

National Endowment for Democracy (2009). Institutionalizing horizontal accountability: How democracies can fight corruption and the abuse of power. Washington, DC: Johns Hopkins University Press.

Neudorfer, S. N., \& Theuerkauf, G. U. (2014). Buying war not peace: The influence of corruption on the risk of ethnic war. Comparative Political Studies, 47 (13), 1856-1886. doi: 10.1177/0010414013516919

Nwadiani, M., \& Omoike, D. (2006). Financing primary, secondary and tertiary education in Nigeria. In J. A. Aghenta \& E. O. Omoregie (Eds.). Fundamentals of educational management (233-255). Agbor: Krisbec Publications.

Organization for Economic Co-operation and Development (OECD) (2008). Public-private partnerships: In pursuit of risk-sharing and value for money. Paper presented at the Public-Private Partnership Seminar. Zurich.

Organization for Economic Co-operation and Development (OECD) (2013). Synergies for better learning: An international perspective on evaluation and assessment. Retrieved from https://www.oecdilibrary.org/docserver/9789264190658en.pdf?expires=1534017579\&id=id\&accname=guest\&checksu $\mathrm{m}=\mathrm{F} 3 \mathrm{EE} 0 \mathrm{DE} 714 \mathrm{E} 7 \mathrm{EEC} 017 \mathrm{EFDB} 1451 \mathrm{~F} 43 \mathrm{CDF}$

Oliver, D. (2010). Complexity in vocational education and training governance. Research in Comparative and International Education, 5 (3), 261-73. doi:10.2304/rcie.2010.5.3.261

Omorogiuwa, O. K. (2006). Research and applied statistics for the behavioural sciences: An introduction. Benin City: Mindex Press.

Oronsaye, A. O. (2016). The anatomy of Nigerian federalism and the physiological imperatives for sustainable development. Paper Presented at the $5^{\text {th }}$ Inaugural Lecture of The Benson Idahosa University, March 2016.

Oxford Advanced Learner's Dictionary (2010). Oxford advanced learner's dictionary of current English: International student's edition ( $8^{\text {th }}$ ed.). New York: Oxford University Press.

Pierre, P., \& Peters, B. G. (2005). Governing complex societies: Trajectories and scenarios. Basingstoke: Palgrave Macmillan.

Savas, E. S. (2000). Privatization and public-private partnership. NY: Chatham House Publishers.

Sharma, M. P., Sadana, B. L., \& Kaur, H. (2013). Public administration: In theory and practice. New Delhi: Kitab Mahal Publishers.

Transparency International (2008). Corruption perceptions index 2008. Retrieved from http://media01.commpartners.com/acc_webcast_docs/TI_CP_Index_2008.pdf

Transparency International (2009). The anti-corruption plain language guide. Retrieved from https://www.transparency.org/whatwedo/publication/the_anti_corruption_plain_language_guide 
Transparency International (2014a). Protecting climate finance an anti-corruption assessment of the UN-REDD programme.

https://www.transparency.org/whatwedo/publication/protecting_climate_finance_un_redd_programme

Transparency International (2014b). Protecting climate finance an anti-corruption assessment of the adaptation fund. Retrieved from content/uploads/2017/04/2017_ProtectingClimateFinance_AFProgressReport_EN.pdf

Transparency International (2016). Redd+ and corruption risks for Africa's forests: Case studies from Cameroon, Ghana, Zambia and Zimbabwe. Retrieved https://www.illegallogging.info/sites/files/chlogging/2016_REDDCorruptionRisksAfrica_EN.pdf https://transparency.eu/wp-

Transparency International (2017a). A handbook for communicators \& journalists on climate change and corruption. Retrieved from https://www.corruptionwatch.org.za/wp-content/uploads/2017/05/2017_Media-Handbook_Climatechange-and-corruption.pdf

Transparency International (2017b). Safeguarding climate finance procurement: Assessment of the procurement policies of the Green Climate Fund. Retrieved on July 2018 at https://www.transparency.org/whatwedo/publication/Nationallevel GCF procurement

Uzoagulu, A. E. (2011). Practical guide to writing research project report in tertiary institutions. Enugu: Cheston Ltd.

U.S. Agency for International Development (USAID) (2008). Public Private Partnerships for Development: A Handbook for Business. Retrieved from http://www.ced.org/2006usaid_partnership.pdf.

Wang, Y. (1999). Public-private partnerships in health and education: Conceptual issues and options. A Manuscript Prepared for Manila Social Policy Forum: The New Social Agenda for East, Southeast and Central Asia. Joint ADBWorld Bank Conference, 9-12 November.

World Bank (2009). The role and impact of public-private partnerships in education. Washington DC. Retrieved from https://openknowledge.worldbank.org/bitstream/handle/10986/2612/479490PUB0Role101OFFICIAL0USE0ONLY1.p df? sequence $=1 \&$ isAllowed $=y$

World Economic Forum (WEF) (2005). Building on the Monterrey consensus: The growing role of public-private partnerships in mobilizing resources for development. Retrieved from http://www.weforum.org/pdf/un_final_report.pdf. 